PUSTABIBLIA: Journal of Library and Information Science

ISSN 2549-3493 (Print); ISSN 2549-3868 (Online)

DOI: http://dx.doi.org/10.18326/pustabiblia.v4i2.209-224

SK Dirjen Risbang-Kemristekdikti No 23/E/KPT/2019 (Peringkat 4 SINTA)

\title{
Pola Information Flows pada Evaluasi Pembelajaran Daring di Masa Pandemi Covid-19
}

\author{
Heni Kartika; Wiji Suwarno \\ Mahasiswa Pascasarjana IAIN Salatiga \\ Pustakawan IA IN Salatiga \\ henikartika2020@gmail.com
}

Diajukan: 20-10-2020; Direview: 21-10-2020; Diterima:21-10-2020;

Direvisi: $12-11-2020$

\begin{abstract}
This writing takes the theme of the online learning process which is motivated by the Covid-19 pandemic situation by taking one of a series of learning processes, namely the learning evaluation process, where learning does not take place normally as usual. This results in changes in the delivery of information within the scope of learning which must be adapted to situations that cannot have a face-to-face, cannot gather in one room, and cannot interact directly with each other, but material information must continue with complete learning targets ). Therefore, this research is interesting to do because it aims to reveal patterns of information flows in learning activities during the Covid-19 pandemic. This research uses qualitative research with a phenomenological approach. This research took a research locus at MI Maarif Mangunsari, Salatiga City. Informants taken in this study were teachers, school principals and parents of students who were taken randomly. The results of this study indicate that first, the implementation of Mangunsari online learning in Salatiga City runs well without significant obstacles due to good planning in terms of teacher competence, materials, facilities and parental involvement, as well as the accuracy of selecting the facilities and infrastructure used in online learning. Second, the process of information flow in online learning forms a triangular pattern between teacher parents and students with the flow of information from teacher to parent through online media, parents to students offline, students to parents, then parents to teachers.
\end{abstract}

Keywords: Information flows, online learning, mastery learning. 


\begin{abstract}
Abstrak
Penulisan ini mengambil tema proses pembelajaran online yang dilatar belakangi oleh situasi pandemi Covid-19 dengan mengambil salah satu rangkaian proses pembelajaran yaitu proses evaluasi pembelajaran, dimana pembelajaran tidak berlangsung normal seperti biasanya. Hal ini mengakibatkan terjadinya perubahan penyampaian informasi dalam ruang lingkup pembelajaran yang harus disesuaikan dengan situasi tidak dapat bertatap muka, tidak dapat berkumpul dalam satu ruangan, dan tidak dapat saling berinteraksi secara langsung, namun informasi materi harus dilanjutkan dengan menyelesaikan target pembelajaran). Oleh karena itu, penelitian ini menarik untuk dilakukan karena bertujuan untuk mengungkap pola arus informasi dalam kegiatan pembelajaran pada saat pandemi Covid-19. Penelitian ini menggunakan jenis penelitian kualitatif dengan pendekatan fenomenologi. Penelitian ini mengambil lokus penelitian di

MI Ma’arif Mangunsari Kota Salatiga. Informan yang diambil dalam penelitian ini adalah guru, kepala sekolah dan orang tua siswa yang diambil secara acak. Hasil penelitian ini menunjukkan bahwa pertama, pelaksanaan pembelajaran online Mangunsari di Kota Salatiga berjalan dengan baik tanpa kendala yang berarti dikarenakan perencanaan yang baik dari segi kompetensi guru, materi, fasilitas dan keterlibatan orang tua, serta ketepatan pemilihan fasilitas dan infrastruktur yang digunakan dalam pembelajaran online. Kedua, proses arus informasi dalam pembelajaran online membentuk pola segitiga antara orang tua guru dan siswa dengan arus informasi dari guru ke orang tua melalui media online, orang tua ke siswa secara offline, siswa ke orang tua, kemudian orang tua ke guru.
\end{abstract}

Kata kunci: Arus informasi, pembelajaran online, ketuntasan belajar.

\title{
A. Latar belakang
}

Wabah virus yang meluas di dunia yang diakibatkan Virus Corona Covid-19 pada pertengahan Maret 2020, membawa perubahan perilaku manusia di seluruh belahan dunia, tidak terkecuali di Indonesia. Tanggap darurat, perlakuan wilayah dengan istilah lock down, strategi pembatasan sosial berskala besar (PSBB) menjadi trend dan dilakukan oleh sebagian besar wilayah di Negara Kesatuan Republik Indonesia.

Keputusan pemerintah sebagai bentuk tanggap terhadap penyebaran wabah ini, salah satunya adalah Keppres Nomor 12 tahun 2020 tentang 
Penetapan Bencana non-alam Penyebaran Covid-19 sebagai Bencana Nasional, memantik respon dari berbagai wilayah untuk ikut serta tanggap terhadap penyebaran virus ini, termasuk di Kota Sentuhan regulasi pemerintah yang diberlakukan menyeluruh di seluruh wilayah NKRI, menjadikan institusi pendidikan pun melakukan hal yang serupa demi mencegah penularan penyakit yang diakibatkan Virus Corona Covid-19 ini. Institusi pendidikan dari sekolah dasar sampai dengan perguruan tinggi memberlakukan hal serupa dengan cara meniadakan semua kegiatan pembelajaran di sekolah-sekolah, tempat-tempat pendidikan formal, maupun di kampus-kampus perguruan tinggi. Dalam konteks informasi, aliran informasi dari guru kepada siswa yang biasanya berjalan normal, mendadak dihadapkan pada situasi yang berbeda dan menuntut daya kreativitas yang tinggi untuk tetap bisa establish dan bertahan.

Sekolah kini seakan-akan diberi sebuah tantangan untuk mampu menjawab fenomena ini. Persoalan terjadi karena secara teori Benjamin S. Bloom melihat bahwa sekolah mempunyai peran dalam pendampingan peserta didik (tutoring) sampai dengan penguasaan materi dengan pembelajaran tuntas (Mastery Learning), ${ }^{1}$ sehingga menjadi tumpuan masyarakat sebagai institusi pendidikan yang dapat mengembangkan potensi peserta didik mencapai kompetensi yang optimal baik aspek kognitif, afektif, maupun psikomotoriknya. Tetapi situasi tidak memungkinkan secara fisik bertemu dan berinteraksi langsung.

Fokus masalah penelitian ini adalah tentang bagaimana pola information flows pada evaluasi pembelajaran daring dalam masa pandemi Covid-19 pada Madrasah Ibtidaiyah, dengan dua pertanyaan sebagai berikut:

1. Bagaimana pelaksanaan pembelajaran daring di MI Ma’arif Kota Salatiga dalam masa pandemi Covid-19?

2. Bagaima pola information flows pada evaluasi pembelajaran daring di MI Ma’arif Kota Salatiga dalam masa pandemi Covid-19?

${ }^{1}$ Benjamin S. Bloom, "The 2 Sigma Problem: The Search for Methods of Group Instruction as Effective as One-to-One Tutoring," Educational Researcher 13, no. 6 (1984): 4. 


\section{B. Kajian pustaka}

Penelitian yang dilakukan oleh Rimbun Rimba Rizki yang mengangkat tema tentang penerapan pembelajaran daring sebagai kombinasi dalam meningkatkan motivasi belajar peserta didik. ${ }^{2}$ Hasil penelitiannya adalah bahwa pertama, implementasi pembelajaran secara daring merupakan kombinasi PKBM Pioneer yang meliputi tahap persiapan, pelaksanaan, dan penilaian. Kedua, penerapan pembelajaran daring kombinasi memiliki dampak yang terhadap motivasi belajar peserta didik siswa. Ketiga, aspekaspek yang pendukung implementasi proses pembelajaran daring dengan metode kombinasi ini meliputi metode pembelajaran, media pembelajaran, dan penataan lingkungan tempat belajar. Sedangkan untuk faktor yang menjadi aspek penghambat adalah cenderung pada kurangnya fasilitas yang dimiliki lembaga.

Penelitian kedua adalah Penelitian yang dilakukan oleh Dindin Jamaludin yang mengambil tema tentang pembelajaran daring masa pandemik Covid-19 pada calon guru ${ }^{3}$ yang menghasilkan temuan ternyata mahasiswa calon guru Paud melakukan pembelajaran dengan cara daring, dan menyesuaikan dengan jadwal perkuliahan.

Ketiga adalah kajian pustaka dari karya Syarifudin yang mengambil tema tentang pembelajaran daring untuk meningkatkan mutu pendidikan, ${ }^{4}$ yang menyimpulkan bahwa kualitas pendidikan dapat ditingkatkan dan dilakukan melalui pembelajaran daring. Siswa akan lebih mahir dalam menguasai materi secara mandiri. Demikian pula, penguasaan kompetensi siswa akan bersifat kontekstual karena materi yang diperoleh adalah sebagai simpulan dari aktivitas siswa yang dilakukan pula dalam suatu konteks.

\footnotetext{
${ }^{2}$ Rimbun Rimbarizki, “Penerapan Pembelajaran Daring Kombinasi Dalam Meningkatkan Motivasi Belajar Peserta Didik Paket C Vokasi Di Pusat Kegiatan Belajar Masyarakat (PKBM) Pioneer Karanganyar," J+ PLUS UNESA 6, no. 2 (2017).

${ }^{3}$ Dindin Jamaluddin et al., "Pembelajaran Daring Masa Pandemik Covid-19 Pada Calon Guru: Hambatan, Solusi Dan Proyeksi," LP2M, 2020.

${ }^{4}$ Albitar Septian Syarifudin, "Impelementasi Pembelajaran Daring Untuk Meningkatkan Mutu Pendidikan Sebagai Dampak Diterapkannya Social Distancing," Jurnal Pendidikan Bahasa Dan Sastra Indonesia Metalingua 5, no. 1 (2020): 31-34.
} 
Dari kajian pustaka di atas memberikan informasi bahwa pembelajaran di berbagai sekolah dilakukan secara daring dengan berbagai cara dan metodenya. Hal yang berbeda dengan penelitian ini adalah bahwa penelitian ini mencari pola aliran informasi (information flows) untuk evaluasi pembelajarannya yang disampaikan guru kepada siswanya.

\section{Landasan teori}

Belajar adalah suatu aktivitas atau suatu proses untuk memperoleh pengetahuan, meningkatkan keterampilan, memperbaiki perilaku, sikap, dan mengokohkan kepribadian. Konteks belajar untuk menjadi tahu atau proses memperoleh pengetahuan, menurut pemahaman sains konvensional adalah kontak manusia dengan alam yang diistilahkan dengan pengalaman (experience) menjadi tahu.

Definisi ini merupakan definisi umum dalam pembelajaran sains secara konvensional, dan beranggapan bahwa pengetahuan sudah tersedia di alam, tinggal pembelajar yang bereksplorasi, menggali dan menemukan informasi sebanyak mungkin untuk menjadikannya sebagai pengetahuan. ${ }^{5}$ Inilah mengapa belajar disebut sebagai titik awal perilaku peradaban, dan guru menjadi sentral perhatian karena guru menjadi pemeran utama dalam proses belajar-mengajar dalam rangka menentukan kualitas hasil pendidikannya. Karena terkadang guru memerankan sebagai model untuk dicontoh dan diidolakan siswanya, kadang guru pula yang berperan sebagai perencana, peramal, pemimpin dan penasehat. ${ }^{6}$

Istilah kedua yaitu daring, ini akronim dari dalam jaringan, yang menggantikan kata online dalam bahasa Inggris yang berati beroperasi dalam jaringan internet, ${ }^{7}$ atau jaringan komunikasi elektronik yang menghubungkan jaringa komputer dengan fasilitas komputer yang terorganisasi di seluruh

${ }^{5}$ Suyono and Hariyanto, Belajar Dan Pembelajaran: Teori Dan Konsep Dasar (Bandung: Rodsa Karya, 2014), 8.

${ }^{6}$ Latifah Husien, Profesi Keguruan: Menjadi guru profesional (Yogyakarta: Pustaka Baru Press, 2017), 66.

7 "Arti Kata Internet - Kamus Besar Bahasa Indonesia (KBBI) Online," accessed May 22, 2020, https://kbbi.web.id/internet. 
dunia melalui telepon atau satelit.

Pembelajaran daring adalah pembelajaran yang dilaskanakan secara terbuka, tidak dibatasi ruang, yang dikemas secara virtual melalui aplikasi pembelajaran online. Meskipun demikian, prinsip mencerdaskan dan memberikan skill dan kompetensi kepada siswa tetap menjadi prinsip yang harus dipatuhi. Pembelajaran daring tetap memperhatikan capaian kompetensinya. Guru seyogyanya mulai menyadari bahwa pembelajaran yang selama ini dilakukan memiliki sifat yang sangat kompleks karena melibatkan aspek paedagogis, psikologis, dan didaktis secara bersamaan. ${ }^{8}$

Jadi pembelajaran merujuk pada suatu upaya atau proses yang membuat situasi belajar. Maka pembelajaran daring dapat diartikan sebagai suatu kegiatan yang berupaya menciptakan situasi belajar melalui media dalam jaringan (daring) internet. Dari kedua istilah ini diperoleh satu istilah baru yang menunjukkan suatu aktivitas pembelajaran pada kondisi yang tidak normal dalam arti tidak ada tatap muka, tidak ada interaksi langsung di kelas, melainkan interaksi di dalam jaringan internet dengan fasilitas komputer atau perangkat lain yang mendukung seperti handphone, laptop, android, dan sebagainya. Pembelajaran yang dilakukan dengan media online tetap melibatkan kehadiran pembelajar dan peserta didik yang berinteraksi langsung atau tidak langsung, tetapi melalui media penghubung dengan aplikasi yang sudah ditentukan dan disepakati seperti halnya WhatsApp, atau media Zoom, atau media Google meet, atau media yang lainnya.

\section{Metode Penelitian}

Jenis penelitian yang digunakan untuk penelitian ini adalah penelitian penelitian kualitatif dengan pendekatan fenomenologi, yakni meneliti tentang kedalaman objek penelitian berdasarkan pada fenomena yang berkembang pada lokus penelitian.

Penelitian ini bertujuan menemukan pola aliran informasi pada pembelajaran daring dalam masa pandemi Covid-19 yang dilakukan di 2013), 100 .

${ }^{8}$ Enco Mulyasa, Pengembangan Dan Implementasi Kurikulum 2013 (PT Remaja Rosdakarya, 
Madrasah Ibtidaiyah. Subjek penelitian pada penelitian ini adalah guru MI dan kepala sekolah MI yang melaksanakan sistem pembelajaran daring selama masa Work From Home. Sementara objek penelitian ini adalah pola information flows dalam pembelajaran daring pada masa pandemi Covid-19 dan WFH. Tempat penelitian adalah MI Maarif Mangunsari, Jl. Abdul Syukur No 03, Cabean, Kel. Mangunsari, Kec. Sidomukti, Kota Salatiga.

Teknis pengumpulan datanya menggunakan interview menggunakan media WhatsApp atau telpon kepada informan. Jenis interview yang digunakan ada dua, pertama interview terstruktur, artinya interview ini sudah dipersiapkan sebagai bahan pertanyaan yang akan disampaikan kepada informan. Jenis kedua adalah interview tidak terstruktur, yaitu berupa pertanyaan yang tidak direncanakan menyesuaikan dengan materi yang disampaikan informan sebagai pengembangan pertanyaan dari pertanyaan terstruktur. Untuk keabsahan datanya menggunakan teknik triangulasi dengan wawancara kepada pihak yang bukan menjadi informan kunci penelitian sebagai langkah mengetahui kebenaran data yang disampaikan.

Metode analisis yang digunakan dalam penelitian ini mengacu pada proses analisis yang dikemukakan oleh Miles dan Huberman yang meliputi empat tahap, yaitu: pengumpulan data, reduksi data, penyajian data dan kesimpulan atau verifikasi.

\section{E. Pola information flows Pada aktivitas pembelajaran daring Di masa pandemi covid-19}

Penerapan kebijakan untuk melakukan pembelajaran daring di semua jenjang pendidikan, melahirkan berbagai strategi dalam rangka menjaga eksistensi pendidikan agar pembelajaran tetap berjalan dan tidak mengurangi hak-hak siswa untuk mendapatkan pendidikan dan pengajaran. MI Ma'arif Mangunsari menggunakan pembelajaran daring pada masa pandemi cofid-19 ini dengan strategi pembelajaran yang sedikit berbeda dengan ketika siswa belajar di kelas. ${ }^{9}$

${ }^{9}$ Wawancara dengan SR tanggal 11 April 2020 
Menurut keterangan TS salah seorang guru yang menjadi informan, bahwa MI Ma’arif pada tanggal 23 Mei 2020, guru MI Ma’arif Mangunsari ini melakukan perisapan-persiapan pelaksanaan pembelajaran daring dalam pandemi covid-19 ini dengan mempersiapkan beberapa aspek:

Pertama, bahwa kesadaran terhadap pentingnya kompetensi guru dalam menguasai IT untuk pembelajaran daring. Para guru juga menyadari bahwa pembelajaran jarak jauh ini tidak dapat menghindar dari tuntutan untuk bisa menguasai berbagai perangkat IT yang dibutuhkan dalam menunjang proses pembelajaran. Ditambahkannya informasi bahwa di madrasah ini perlu ada penguatan terhadap kompetensi guru dalam menguasai IT sebagai upaya menciptakan pembelajaran yang lebih menarik dan efektif.

Guru yang sukses bukanlah sekedar penyaji yang kharismatik dan persuasif. Lebih jauh, guru yang sukses adalah mereka yang melibatkan siswa dalam tugas-tugas yang syarat dengan muatan kognitif, dan sosial, dan mengajari mereka bagaimana mengerjakan tugas-tugas tersebut secara produktif. Sedangkan para pembelajar yang efektif adalah mereka yang mampu menggambarkan informasi, gagasan, dan kebijaksanaan dari guruguru mereka dan menggunakan sumber-sumber belajar secara efektif. Termasuk dalam konteks masa pandemi Covid-19 dan WFH ini guru-guru berupaya menyajikan proses pembelajaran yang efektif melalui pembelajaran daring, dimulai dari persiapan. Berikut dapat digambarkan skema persiapan pembelajaran daring yang dilakukan di MI Ma’arif Mangunsari.

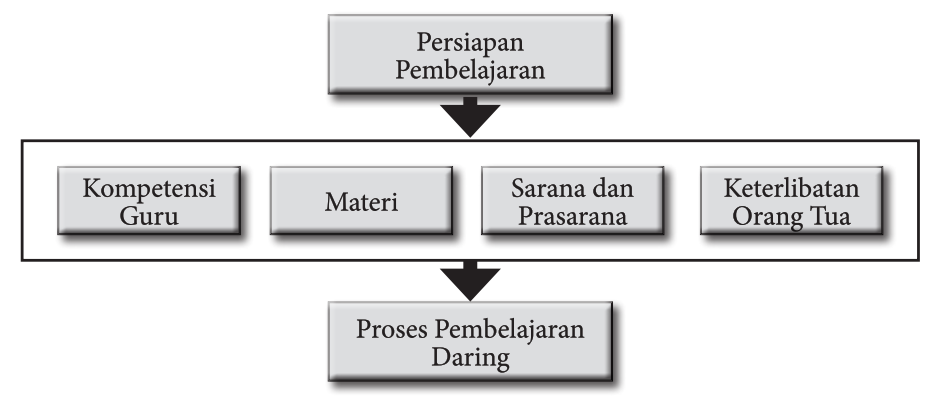

Gambar 1. Skema persiapan pembelajaran daring MI Ma'arif Mangunsari 
Dari skema di atas dapat dilanjutkan kembali pada proses pembelajarannya dengan skema sebagai berikut:

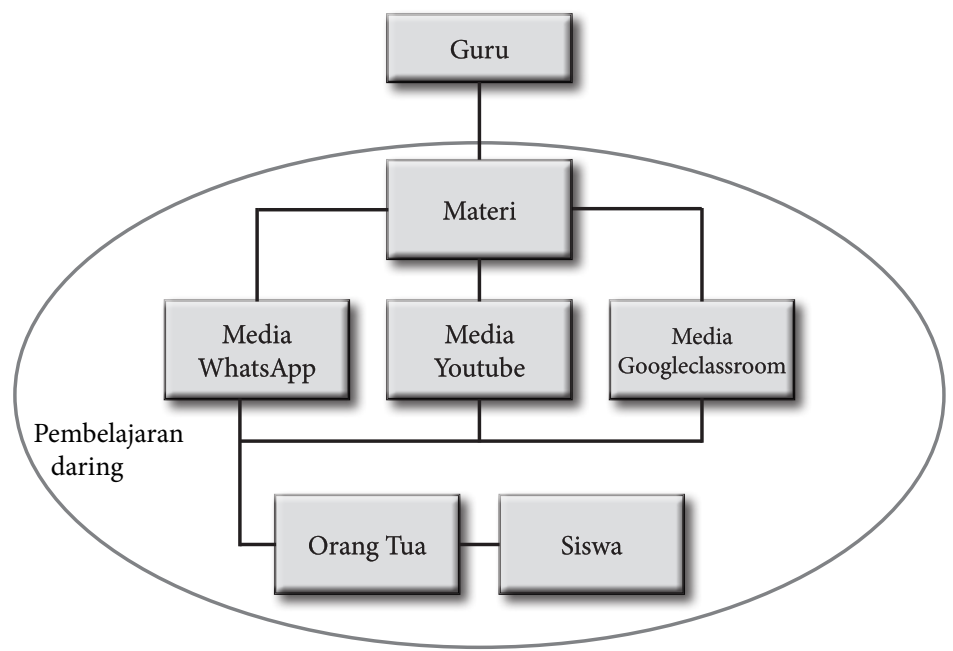

\section{Gambar 2. Skema proses pembelajaran daring MI Ma’arif Mangunsari}

Pelaksanaan pembelajaran daring telah dipraktikan sebagai sarana mengatasi kegalauan akademik yang melarang individu untuk berkumpul dan berinteraksi langsung. Pembelajaran daring ini juga menyesuaikan materi dengan jadwal yang sudah dibuat, dan menyusun materi yang akan disampaikan dan materi yang sudah dibuat dengan rapi pada lembar kerja di MS.Word, atau power point, dan atau video, kemudian guru mengirim materi melalui WA atau youtube.

Persiapan yang dilakukan MI Ma'arif Mangunsari ini sudah memadai. Dibuktikan dengan kebijakan yang cepat dari kepala sekolah untuk memberikan kesempatan guru-guru untuk kursus tentang media pembelajaran yang diperlukan untuk menunjang pembelajaran daring. Kompetensi guru dalam bidang IT ditingkatkan, dan pemilihan media yang tepat, membuat proses pembelajaran daring di MI ini tidak mengalami hambatan yang berarti.

Pada pembelajaran daring ini, pelibatan orang tua menjadi pertimbangan penting, dimana berdasarkan penuturan informan, orang 
tua ini berfungsi menjadi "guru bayangan" yang menggantikan peran guru sewaktu di rumah.

Menengok kembali informasi yang disampaikan informan mengenai praktik Mastery Learning dalam pembelajaran daring di MI Maarif Mangunsari dapat dikatakan bahwa Mastery Learning ini adalah sebuah konsep dengan mengedepankan kompetensi personal. Praktik Mastery Learning sudah berjalan di MI Ma'arif Mangunsari sejak sebelum diberlakukannya pembelajaran daring. Namun demikian dirasakan justru Mastery Learning ini lebih terasa ketika diterapkan pada pembelajaran daring ini pada tataran kemandirian dan kemerdekaan belajar.

Praktik Mastery Learning pada pembelajaran daring. Guru MI Ma’arif Mangunsari telah berlaku sistematis sebagaimana yang dikehendaki oleh konsep Mastery Learning yakni penyampaian materi dimulai dari perencanaan (orientasi), penyajian (pelaksanaan) hingga evaluasi telah dirancang sedemikian rupa dan diatur secara sistematis. Terdapat beberapa hal yang menurut informan penting untuk disampaikan bahwa para guru telah membuat rencana pelaksanaan pembelajaran. Rencana pelaksanaan pembelajaran (RPP) dibuat untuk satu kali pembelajaran dan dipakai sebagai pedoman guru serta diberikan kepada siswa. Lebih lanjut dijelaskannya bahwa jika pada pembelajaran normal materi disampaikan di kelas, maka pada saat pembelajaran daring ini materi diposting di WA dan atau diunggah di youtube, kemudian nanti siswa diberi link untuk mempelajari materi itu. Hal ini dilakukan karena dengan cara menyampaikan materi secara audio visual, diasumsikan bahwa cara ini akan membantu siswa untuk memahami materi secara lebih jelas.

Pada prinsipnya dikatakan bahwa pembelajaran daring ini mengikuti kurikulum yang sudah berjalan, hanya ruang dan waktunya yang sekarang menjadi pembeda. Ruang menjadi melalaui virual dan waktu tidak terjadwal seperti halnya di kelas.

Pada skema proses belajar tersebut, terdapat satu hal yang berbeda, yakni keterlibatan orang tua yang masuk dalam lingkaran pembelajaran 
daring. Skema ini dilakukan secara konsisten oleh MI Ma'arif Mangunsari sebagai bentuk pengawasan secara langsung oleh orang tua kepada anak didiknya. Hal ini menjadi menarik, mengingat selama pembelajaran berlangsung dalam situasi normal, keterlibatan orang tua dalam proses pembelajarang bisa dikatakan minimal, lebih dominan pihak sekolah dalam hal ini guru yang masuk dalam lingkaran pembelajaran.

Selanjutnya orang tua menugaskan putra putrinya sesuai instruksi dari guru, baik mempelajari materi atau mengerjakan tugas. Proses selanjutnya siswa melakukan sesuai instruksi. Di tahap ini, diharapkan orang tua turut aktif mengawasi, dan atau berperan sebagai guru di rumah. Setelah siswa melakukan tugasnya, siswa melaporkannya kepada orang tua. Ini dilakukan sebagai bentuk keterlibatan orang tua dalam hal pengawasan terhadap siswa. Pada tahap ini orang tua bisa mengontrol tugas atau pekerjaan putra/putrinya, memberi arahan, memberi sugesti dan hal-hal lain yang dianggap membantu putra/putrinya untuk berkembang.

Media dalam konteks pembelajaran merupakan alat yang mempunyai fungsi menjadi perantara penyampai pesan pembelajaran. Penggunaan media dengan benar dapat berpengaruh terhadap hasil akhir tujuan pembelajaran. Semakin baik menggunakan, memungkinkan mendapatkan hasil pembelajaran yang baik pula.

Hasil akhir ini bisa dilihat dari evaluasi dari proses yang sudah dilakukan. Menanggapi pertanyaan menganai bagiamana proses evaluasi pembelajaran daring yang selama ini berjalan terkait dengan Mastery Learning yang dijadikan prinsipnya, SR selaku kepala sekolah memberikan keterangan bahwa proses evaluasi tetap dilakukan secara daring, pengiriman tugas dan lain-lain yang terkait dengan interaksi dengan personal diminimalisir, bahkan nyaris ditiadakan.

Menindaklanjuti pernyataan TS ini muncul pertanyaan kembali tentang peran siswa pada sistem ini. TS memberi keterangan bahwa siswa dalam posisi sebagai subjek pembelajaran dan di posisi tengah antara guru dan orang tua. Siwa mempelajari dan mengerjakan semua tugas yang 
sudah disiapkan guru yang dikirim kepada orang tua melalui media. Siswa bisa bertanya dan berinteraksi secara langsung dengan orang tua, atau bahkan dengan gurunya. Perbedaannya jika interaksi dengan guru harus menggunakan media, tetapi jika berinterkasi dengan orang tua (wali) bisa dilakukan secara langsung. ${ }^{10}$

Di sisi lain, KR melihat peran siswa ini sebagai media bertemunya orang tua dengan guru. Menurutnya, dengan adanya pembelajaran daring ini, antara orang tua dan guru malah justru bisa lebih sering berkomunikasi. Orang tua bisa menyampaikan hal-hal yang kurang dari putra/putrinya atau menyampaikan hal-hal yang kurang dari sistem pembelajarannya. Misalnya keterbatasan kuota sehingga terlambatnya respon terhadap tugas, atau kegiatan atau pekerjaan yang belum memungkinkan melihat tugas atau materi yang diberikan guru, sehingga memperlambat tarsampaikannya kepada putra/putrinya. ${ }^{11}$

Kompetensi guru yang mumpuni, mampu mengoperasikan berbagai perangkat daring, mampu menyusun materi yang inovatif dan kreatif, mampu berkomunikasi dengan orang tua secara baik ${ }^{12}$ adalah syarat awal suksesnya target pencapaian pembelajaran daring. Pembelajaran yang diawali dari proses perencanaan (orientasi) yang dilanjutkan dengan penyajian dan diakhiri dengan evaluasi, secara umum berlaku pada pembelajaran secara umum pada kondisi normal. Saat ini pembelajaran konvensional sementara ditinggalkan, dan pembelajaran daring menjadi istimewa karena mendobrak tradisi pembelajaran konvensional yang terdapat aktivitas bertatap muka, interaksi di dalam kelas, dan berkerumun. Berikut pola penyampaian informasi yang terjadi pada pembelajaran daring:

\footnotetext{
${ }^{10}$ Wawancara dengan TS, 23 Mei 2020.

${ }^{11}$ Wawancara dengan KR, 25 Mei 2020.

${ }^{12}$ Dirjen Pendasmen, Standar Kompetensi Guru SLB, SD, SMP, SMU (Jakarta: Kemendikbud, 2013).
} 


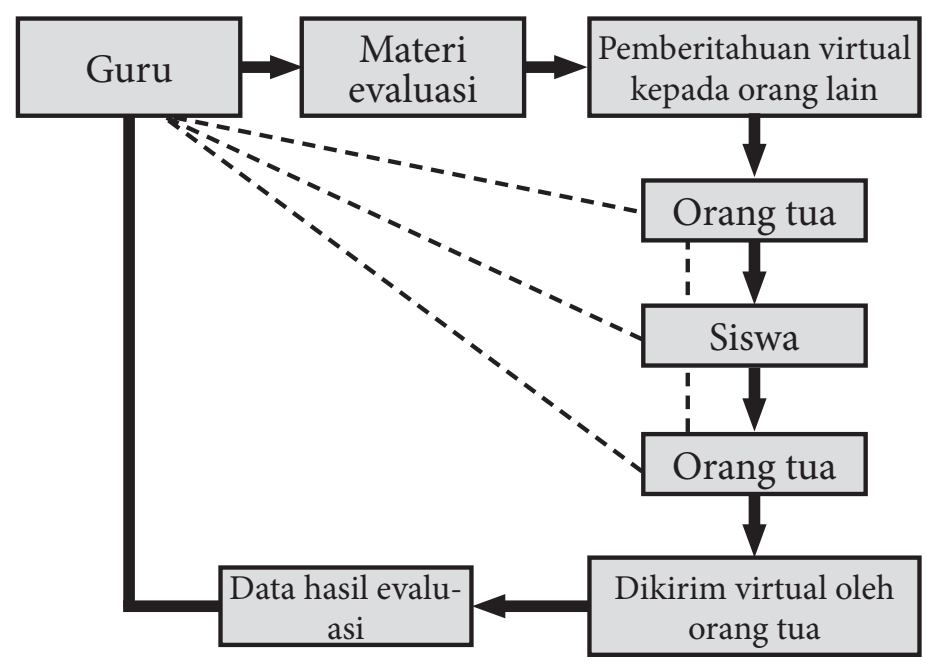

\section{Gambar 3. Pola information flows pada evaluasi pembelajaran daring MI Ma'arif Mangunsari}

Jika merujuk pada konsepnya Bloom, pada skema ini dapat dilihat bahwa pembelajaran tuntas (Mastery Learning) terlihat pada proses penugasan dari persiapan (orientasi) guru membuat materi evaluasi, pemberian tugas (penyajian), dan data hasil pengerjaan tugas (evaluasi) kepada siswa yang terawasi oleh orang tua. Evaluasi dapat dikatakan pula suatu kegiatan untuk menilai seberapa jauh program telah berjalan seperti yang telah direncanakan. Evaluasi dapat dimaknai pula sebagai suatu alat untuk menentukan apakah tujuan pendidikan dan apakah proses dalam pengembangan ilmu telah berada dijalan yang diharapkan. ${ }^{13}$

Diharapkan dari sisi ini siswa mendapatkan bimbingan dan pengawasan maksimal dari orang tua. Jika ada kendala, maka garis terputus menunjukkan pola komunikasi segitiga yang bisa dilakukan antara guru, siswa dan orang tua siswa. Jadi evaluasi dalam konteks ini adalah kegiatan menilai atau mengevaluasi hal-hal yang dilakukan dalam proses pembelajaran meliputi perencanaan, pelaksanaan dan proses penilaian serta dampaknya terhadap peserta didik.

\footnotetext{
${ }^{13}$ Akhmad Riadi, “Problematika Sistem Evaluasi Pembelajaran,” ITTIHAD 15, no. 27 (2017): 3.
} 
Evaluasi ini dilakukan dengan tujuan dapat memperbaiki kekurangan dalam pembelajaran, dan dapat dijadikan dasar untuk proses pembelajarannya selanjutnya.

\section{F. Kesimpulan dan Penutup}

Sebagai penutup, dapat disampaikan suatu simpulan bahwa:

Pertama, pelaksanaan pembelajaran daring pada MI Ma'arif Mangunsari Kota Salatiga berlangsung baik tanpa kendala berarti dikarenakan perencanaan yang baik dari segi kompetensi guru, materi, sarana dan keterlibatan orang tua, serta ketepatan pemilihan sarana dan prasana (perangkat) yang digunakan dalam pembelajaran daring.

Kedua, bahwa pelaksanaan terdapat pola informasi baru yang muncul dari budaya pembelajaran daring ini dalam rangka menyampaikan materi kepada siswa. Yaitu pola guru - media - orang tua - siswa - orang tua media - guru.

\section{DAFTAR PUSTAKA}

"Arti Kata Internet - Kamus Besar Bahasa Indonesia (KBBI) Online." Accessed May 22, 2020. https://kbbi.web.id/internet.

Bloom, Benjamin S. "The 2 Sigma Problem: The Search for Methods of Group Instruction as Effective as One-to-One Tutoring." Educational Researcher 13, no. 6 (1984): 4-16.

Cox Jr, William F., and Thomas G. Dunn. "Mastery Learning: A Psychological

Trap?” Educational Psychologist 14, no. 1 (1979): 24-29.

Husien, Latifah. Profesi Keguruan: Menjadi guru profesional. Yogyakarta: Pustaka Baru Press, 2017.

Jamaluddin, Dindin, Teti Ratnasih, Heri Gunawan, and Epa Paujiah.

"Pembelajaran Daring Masa Pandemik Covid-19 Pada Calon Guru:

Hambatan, Solusi Dan Proyeksi." LP2M, 2020.

Mulyasa, Enco. Pengembangan Dan Implementasi Kurikulum 2013. PT Remaja Rosdakarya, 2013. 
Pendasmen, Dirjen. Standar Kompetensi Guru SLB, SD, SMP, SMU. Jakarta: Kemendikbud, 2013.

Riadi, Akhmad. "Problematika Sistem Evaluasi Pembelajaran." ITTIHAD 15, no. 27 (2017).

Rimbarizki, Rimbun. "Penerapan Pembelajaran Daring Kombinasi Dalam Meningkatkan Motivasi Belajar Peserta Didik Paket C Vokasi Di Pusat Kegiatan Belajar Masyarakat (PKBM) Pioneer Karanganyar." J+ PLUS UNESA 6, no. 2 (2017).

Suyono, and Hariyanto. Belajar Dan Pembelajaran: Teori Dan Konsep Dasar. Bandung: Rodsa Karya, 2014.

Syarifudin, Albitar Septian. "Impelementasi Pembelajaran Daring Untuk Meningkatkan Mutu Pendidikan Sebagai Dampak Diterapkannya Social Distancing." Jurnal Pendidikan Bahasa Dan Sastra Indonesia Metalingua 5, no. 1 (2020): 31-34. 
Heni Kartika 